\title{
REVISED PAPER: NEONICOTINOIDS AS A POTENTIAL THREAT TO HONEY - DEVELOPMENT OF LIQUID CHROMATOGRAPHY METHODS FOR THEIR DETERMINATION
}

\section{REVIDIRANI RAD: NEONIKOTINOIDI KAO POTENCIJALNA OPASNOST ZA MED - RAZVOJ TEČNO-HRAMATOGRAFSKIH METODA ZA NJIHOVO ODREĐIVANJE}

\author{
Pavle JOVANOV, Marijana SAKAČ, Bojana ŠARIĆ, Ivan MILOVANOVIĆ, Dubravka JAMBREC, Ljubiša ŠARIĆ, Jovana KOS \\ University of Novi Sad, Institute of Food Technology in Novi Sad, 21000 Novi Sad, Bulevar cara Lazara 1, Serbia \\ e-mail: pavle.jovanov@fins.uns.ac.rs
}

\begin{abstract}
There is an increasing interest on neonicotinoid residues determination in honey samples because they are banned by European Union. Their determination is based on liquid chromatography analytical methods and, therefore, the aim of this study was to develop the analytical method for quantifying these compounds using different sample preparation techniques. The sample preparation was conducted by two different techniques and the new HPLC-DAD method was developed and validated assuring reliable accuracy $(R, 70-120 \%)$, repeatability (RSD, < $20 \%)$ and within-laboratory reproducibility (RSD, <20\%). Also, low limits of detection and quantification (LOD, 2.5-5.0 $\mu \mathrm{g} \mathrm{kg}^{-1}$; LOQ, 7.5-10.0 $\mathrm{g} \mathrm{kg}^{-1}$ ) for the mentioned method were achieved. To address the importance of honey safety control more than 100 samples from Vojvodina region were analyzed showing residues of neonicotinoids. The HPLC-MS/MS method was used to confirm the presence of neonicotinoids quantified using validated HPLCDAD method.
\end{abstract}

Keywords: Neonicotinoids, liquid chromatography, DLLME, QuEChERS, honey.

\section{REZIME}

Nakon što je Evropska unija ograničila korišćenje neonikotinoida na cvetnim usevíma koje pčele posećuju, došlo je do povećanog interesovanja za utvrđivanje ostataka neonikotinoida u pčelinjim proizvodima poput meda. Stoga je cilj ovog istraživanja bio razvoj analitičkih metoda, zasnovanih na tečnoj hromatografiji, korišćenjem dve tehnike za pripremu uzoraka, za određivanje odabranih neonikotinoida u uzorcima meda. Priprema uzoraka meda za analizu odabranih neonikotinoida ostvarena je optimizacijom dve tehnike pripreme čime je potrvđeno da one ispunjavaju uslove propisane u SANCO/12571/2013 standardu za validaciju, obezbeđujući rezultate za tačnost ( $R, 70-120 \%$ ), ponovljivost (RSD, <20\%) i unutar-laboratorijsku reproduktivnost (RSD, < 20\%), kao i granicu detekcije (LOD, 2.5-5.0 $\mu \mathrm{g} \mathrm{kg}^{-1}$ ) i kvantífikacije (LOQ, 7.5-10.0 $\mu \mathrm{g} \mathrm{kg}^{-1}$ ) korišćenjem DAD detektora. Aplikativnost metoda je potvrđena na više od 100 uzoraka medarazličitog cvetnog porekla (suncokretovog, lipinog, bagremovog i livadskog meda), prikupljenih iz 7 okruga Autonomne Pokrajine Vojvodine, čijom analizom je ustanovljeno prisustvo određenih neonikotinoida, što je ukazalo na neophodnost permanentne kontrole ove vrste namirnica na ostatke pesticida.

Ključne reči: neonikotinoidi, tečna hromatografija, DLLME, QuEChERS, med.

\section{INTRODUCTION}

The most widely used class of the insecticides in last 20 years are neonicotinoids, which act as a receptor agonists of nicotinic acetylcholine (Decourtye and Devillers, 2010; Tomizawa and Casida, 2005). Systemic translocation to the whole plant (flowers, pollen and nectar) through xylemic and phloemic transport results in their presence on the leaves through guttation (van der Sluijs ex al., 2013), allowing pathways by which honey bees among other beneficial pollinators can be relived to these insecticides. Different studies in Europe and USA demonstrated that sublethal amounts of neonicotinoids cause disorientation, reduced communication, impaired learning and memory, reduced longevity and disruption of honeybee brood cycles (Farooqui, 2013). The residues of neonicotinoids may be found in honey, pollen and other bee product (Kasiotis et al., 2014; Tanner and Czerwenka, 2011). Due to their evidenced negative impact, the European Commission issued two-year ban for the use of thiamethoxam, imidacloprid and clothianidin in crops attractive to bees (Commission, 2013; EFSA, 2013). Having that in mind, determination of neonicotinoids in honey has become necessary and requires sensitive, selective and efficient analytical methods. The residue of neonicotinoids in honey samples can be measured by liquid chromatography (LC) coupled to different detectors such as diode array detector (DAD) (Campillo et al., 2013; Jovanov et al., 2015) or mass spectrometer (MS or MS/MS) (Fidente et al., 2005; Jovanov et al., 2013; Jovanov et al., 2014; Lazić et al., 2014). The MS/MS detector assures high sensitivity and selectivity compared to $\mathrm{DAD}$, but it is an expensive and high maintenance instrument. In addition, the optimized sample preparation procedures are needed to achieve good performance characteristics. Therefore, the main goal of this research was development of rapid, sensitive, optimized and reliable liquid chromatography method with DAD detector in alliance with chosen extraction techniques for determination of dinotefuran, thiamethoxam, clothianidin, acetamiprid, imidacloprid, nitenpyram, and thiacloprid in honey. The proposed method was validated and applied to around hundred honey samples for the presence of the neonicotinoids (Jovanov, 2014).

\section{MATERIAL AND METHOD}

Chemicals and reagents

Neonicotinoin standards (certified purity > $99 \%$ ) and formic acid (purity $98 \%$, w/w) were obtained from Sigma-Aldrich (Steinheim, Germany), while acetonitrile and dichloromethane 
(HPLC grade) were bought from Merck (Darmstadt, Germany). Simplicity UV Millipore system (Bedford, MA, USA) was used to obtain purified water. Stock solutions $\left(100.0 \mathrm{mg} \mathrm{L}^{-1}\right)$ were prepared using purified water and be stable over a three-month period when stored at $-10{ }^{\circ} \mathrm{C}$. Multicomponent standard solution (100.0 $\mu \mathrm{g} \mathrm{L}^{-1}$ ) was used for matrix-matched and solvent based calibration (MMC and SC, respectively) and for spiking honey samples. The MMC standards were obtained by using blank honey samples spiked with multicomponent stock solution over the range from the limit of quantification (LOQ) to $100.0 \mu \mathrm{g} \mathrm{kg}^{-1}$. All standard solutions could be stable over a onemonth period when stored at $4{ }^{\circ} \mathrm{C}$, protected from light. United Chemical Technologies QuEChERS sample preparation kits (buffered extraction kits part number ECQUEU750CT and general cleanup kits part number ECMPS15CT) were used for the extraction protocols.

\section{Sample collection and preparation}

Sunflower, wildflower, linden, and acacia honey samples, collected from 7 different regions of the Autonomous Province of Vojvodina, Republic of Serbia were subjected for the analysis. This study was conducted using $50.0 \mathrm{~g} \mathrm{~L}^{-1}$ of honey solution prepared in water and spiked with neonicotinoid multicomponent solutions on different concentration levels. Prior to analysis all spiked samples were left to "equilibrate" overnight.

\section{Extraction protocols}

Before the chromatographic separation two extraction methods were used for sample preparation - DLLME and QuEChERS methods (Fig. 1).

gradient program: at start $90 \%$ of solvent B linearly reached $60 \%$ after 6 min and then went back to $90 \%$ at 10 min at the end of the run. The retention times were used to identify the investigated neonicotinoids, while quantification was based on peak areas. The DAD wavelengths were set at 244 and $266 \mathrm{~nm}$.

\section{LC-MS/MS confirmation analysis}

The same liquid chromatograph (Agilent 1200 Series, Agilent Technologies Inc., USA) was used as for the HPLC$\mathrm{DAD}$ analysis. The isocratic elution at a flow rate of $0.5 \mathrm{~mL}$ $\mathrm{min}^{-1}$ was performed using ultrapure water with $0.1 \%$ formic acid and ACN with the ratio 20:80 (v/v). An Agilent 6410 Triple Quad LC/MS mass spectrometer (Agilent Technologies Inc., USA) supplied with MassHunter software version B.03.01 (Agilent Technologies Inc., USA) was ised with a multimode interface in positive ion mode to conduct the analysis. The heater gas temperature of $325{ }^{\circ} \mathrm{C}$ and vaporzation temperature of 200 ${ }^{\circ} \mathrm{C}$ was applied. As a nebulizer gas nitrogen was used (50 psi, a flow rate - of $5 \mathrm{~L} \mathrm{~min}{ }^{-1}$; capillary voltage $-2500 \mathrm{~V}$; charging voltage - $2000 \mathrm{~V}$ ). Total ion chromatograms (TIC) were recorded for all investigated neonicotinoids in the multiple reaction monitoring (MRM) mode using a dwell time of 20 milliseconds (msec) and the most intense transitions for each investigated compound.

\section{Method validation}

The developed method was tested to find out if it satisfied all requirements of method validation procedures for pesticides residue analysis in foods (SANCO/12571/2013). The calibration curves were constructed for all neonicotinoids dissolved in pure solvent and in honey matrix (LOQ to $100.0 \mu \mathrm{g} \mathrm{kg}^{-1}$ for both) by plotting the peak areas against the

- $5.0 \mathrm{~mL}$ of the honey sample (blank or spiked), (DHM) (extraction solvent) and $0.5 \mathrm{~mL}$ of acetonitrile (ACN) (dispersive solvent) were added into a $10.0 \mathrm{~mL}$ round-bottom tube.

- The tube was shaken for 1 min by vortex (BOECO, Gern $10 \mathrm{~min}$ in the ultrasonic bath (L\&R ultrasonics LTD Unit) and soaked for $\mathrm{kHz}, 400 \mathrm{~W}$ ). Shaking was repeated for 1 in.

The tube was centrifuged for 5 min at 2500 rpm (Tehtnica, Yugoslavia).

- The sediment was removed by a syringe and collected in another test tube.

- The dichloromethane was evaporated under the flow of air using the ReactiTherm heating module (Thermo-Scient

- The final residue was reconstituted with $0.2 \mathrm{~mL}$ of mobile phase and shaken by vortex for 2 min.

- Samples were transferred into the vials for further analysis.

concentrations. The square correlation coefficient $\left(\mathrm{r}^{2}\right)$ was used to express the linearity of calibration curves. The limit of detection (LOD) and limit of quantification (LOQ) were also estimated using matrixmatched standards, while the accuracy of the applied method was determined as recovery $(\mathrm{R}, \%)$ and the precision of developed method was expressed as repeatability and within-laboratory reproducibility.

\section{RESULTS AND DISCUSSION}

Residue-analysis methods (concentration less than $\mu \mathrm{g} \mathrm{L}^{-1}$ ) require the special attention when the pretreatment procedure is chosen. Therefore, two pretreatment procedures were tested (DLLME and QuEChERS) as the neonicotinoid extraction methods from honey samples. The QuEChERS procedure was followed by higher matrix influence compared to the DLLME pretreatment procedure due to higher polarity of the extraction solvent applied in the QuEChERS procedure, which ensured the higher amount of coextracted neonicotinoids. The observed

\section{HPLC-DAD analysis}

Liquid chromatograph (Agilent 1200 Series, Agilent Technologies Inc., USA), equipped with DAD detector and ZORBAX Eclipse XDB-C18 column (50 mm $\times 4.6 \mathrm{~mm}$ i.d., 1.8 $\mu \mathrm{m})$, was used for separation and quantification of neonicotinoids in the obtained extracts. The column temperature was $30^{\circ} \mathrm{C}$ and the sample injection volume of $10 \mu \mathrm{L}$ was applied. The mobile phase consisted of two eluents, ACN (A) and ultrapure water with $0.2 \%$ formic acid (B). A flow rate was $0.7 \mathrm{~mL} \mathrm{~min}{ }^{-1}$. The neonicotinoids were separated applying the matrix effect required the using the matrix-matched standards and matrix-matched calibration curves, which were linear over the range LOQ- $100.0 \mu \mathrm{g} \mathrm{kg}^{-1}$.

The accuracy of the proposed method was expressed as the mean recovery ( $\mathrm{R}, \%$ ) where $\mathrm{R}$ and RSD values were determined using a spiked blank honey samples in 5 replicates at 10.0, 50.0 and $100.0 \mu \mathrm{g} \mathrm{kg}^{-1}$ concentration levels calculated with MMC curves. The recovery results showed that both extraction methods provided optimal neonicotinoids recovery (70-120\% at each spiking level with RSD of $\leq 20 \%$ ). Precision, expressed as 
the repeatability and within-laboratory reproducibility with RSD values less than $20 \%$ assured a good precision of both developed extraction methods. Limits of detection and limits of quantification are the indicators of method sensitivity in residue analysis, and with the achieved LODs of 2.5-5.0 $\mathrm{\mu g} \mathrm{kg}^{-1}$ and LOQs of $7.5-10.0 \mu \mathrm{g} \mathrm{kg}^{-1}$ we can assume that this method is applicable for the neonicotinoid residue analysis. Furthermore, the obtained LOQs were much lower than the European Commission MRLs for all neonicotinoids in honey. Applicability of the developed method was tested on the analysis of 104 honey samples from different plant origin (51 sunflower, 26 wildflower, 22 acacia and 5 lindens) for neonicotinoid residues. After preparing honey samples using QuEChERS procedure, the obtained results showed the presence of the thiacloprid in 5 honey samples in quantities below EU MRL. The extraction of the neonicotinoids was repeated using the DLLME procedure on thiacloprid contaminated honey samples, and the obtained quantification results showed excellent matching of two extraction methods $(p<0.05)$, indicating that depending of resources both sample preparation methods can be used for neonicotinoid analysis with HPLC-DAD system. Results confirmation was performed using previously developed LC-MS/MS method (Jovanov et al., 2013).

\section{CONCLUSION}

Developed HPLC-DAD method with the DLLME and QuEChERS procedures was applied for the analysis of the selected neonicotinoids in honey samples collected from the Autonomous Province of Vojvodina. The validation results made possible low concentration level quantification of selected neonicotinoids. Neonicotinoid thiacloprid, mostly used for the crops protection was found in residue levels below MRL implicating the importance of permanent honey samples control.

ACKNOWLEDGMENT: The authors appreciate fundi from the Ministry of Education and Science of the Republic Serbia (Project No. ON172012 and TR31029) for supporting this effort.

\section{REFERENCES}

Campillo, N., Viñas, P., Férez-Melgarejo, G., HernándezCórdoba, M. (2013). Liquid chromatography with diode array detection and tandem mass spectrometry for the determination of neonicotinoid insecticides in honey samples using dispersive liquid-liquid microextraction. Journal of Agricultural and Food Chemistry, 61, 4799-4805.

Commission, T.E. (2013). Commission implementing regulation (EU) No 485/2013. Official Journal of the European Union.

Decourtye, A., Devillers, J. (2010). Ecotoxicity of neonicotinoid insecticides to bees. Advances in Experimental Medicine and Biology, 683, 85-95.

EFSA (2013). European Food Safety Authority. Conclusion on the peer review of the pesticide risk assessment for bees for the active substance thiamethoxam. EFSA Journal, 11, 3067-3068.
Farooqui, T. (2013). A potential link among biogenic aminesbased pesticides, learning and memory, and colony collapse disorder: A unique hypothesis. Neurochemistry International, 62, 122-136.

Jovanov, P. (2014). Optimizacija metoda ekstrakcije i određivanja neonikotinoida tečnom hromatografijom u odabranim uzorcima, Prirodno-matematički fakultet, Univerzitet u Novom Sadu, Novi Sad, Srbija.

Jovanov, P., Guzsvány, V., Franko, M., Lazić, S., Sakač, M., Milovanović, I., Nedeljković, N. (2014). Development of multiresidue DLLME and QuEChERS based LC-MS/MS method for determination of selected neonicotinoid insecticides in honey liqueur. Food Research International, 55, 11-19.

Jovanov, P., Guzsvány, V., Franko, M., Lazić, S., Sakač, M., Šarić, B., Banjac, V. (2013) Multi-residue method for determination of selected neonicotinoid insecticides in honey using optimized dispersive liquid-liquid microxtraction combined with liquid chromatography-tandem mass spectrometry. Talanta, 111, 125-133.

Jovanov, P., Guzsyány, V., Lazié, S., Franko, M., Sakač, M., Šarić, L., Kos, J. (2015). Development of HPLC-DAD method for determination of neonicotinoids in honey. Journal of Food Composition and Analysis, 40,

Kasiotis, K., Anagnostopoulos, C., Anastasiadou, P., Machera., K. (2014). Pesticide residue in honeybees, honey and bee pollen by LC-MS/MS screening: Reported death incidents in oneybees. Science of the Total Environment, 485-486, 63342.

Lazić, S., Šunjka, D., Panić, S., Inđić, D., Grahovac, N., Guzsvány, Y.J Jovanov, P. (2014). Dissipation rate of acetamiprid in sweet cherries. Pesticidi i fitomedicina, 29, 7582

ANCO/12571/2013. Method validation and quality control procedures for pesticide residues analysis in food and feed.

Tanner, G., Czerwenka, C. (2011). LC-MS/MS analysis of neonicotinoid insecticides in honey: methodology and residue findings in Austrian honeys. Journal of Agricultural and Food Chemisty, 59, 12271-12277.

Tomizawa, M., Casida, J. E. (2005). Neonicotinoid insecticide toxicology: mechanisms of selective action. Annual Review of Pharmacology and Toxicology, 45, 247-268.

Van der Sluijs, J. P., Simon-Delso, N., Goulson, D., Maxim, L., Bonmatin, J.-M., Belzunces, L. P. (2013). Neonicotinoids, bee disorders and the sustainability of pollinator services. Current Opinion in Environmental Sustainability, 5, 293-305.

Received: 21. 12. 2016.

Accepted: 25. 01. 2017. 